\title{
Characterization of 410NiMo Coatings Deposited By Thermal Spray And Re- Cast With TIG On CA6NM Martensitic Stainless Steel Against Cavitation Erosion
}

Émillyn Ferreira Trevisani Olivio ( $\nabla$ emillynf@utfpr.edu.br)

Universidade Tecnologica Federal do Parana https://orcid.org/0000-0003-2429-4392

Paulo Sergio Olivio Filho

Federal University of Paraná

Janaina Fracaro de Souza

Universidade Tecnologica Federal do Parana

Paulo Victor Prestes Marcondes

Federal University of Paraná

João Roberto Sartori Moreno

Universidade Tecnologica Federal do Parana

\section{Research Article}

Keywords: Thermal Spraying, Remelting, TIG, Cavitation Erosion, CA6NM Steel, 410NiMo

Posted Date: June 2nd, 2021

DOI: https://doi.org/10.21203/rs.3.rs-535588/v1

License: (c) (i) This work is licensed under a Creative Commons Attribution 4.0 International License.

Read Full License 


\section{Abstract}

In most applications, martensitic stainless steels are subjected to operating conditions in which good mechanical properties and wear resistance are required. CA6NM is a soft martensitic stainless steel that has high shear stress and toughness, good resistance to corrosion and cavitation, and better weldability than conventional martensitic stainless steels. These steels are susceptible to cavitation erosion which is the process of removing material due to the progressive action of erosive wear caused by the implosion of bubbles close to the surface of the mechanical element. Welding and thermal spraying are normally used to produce coatings when there is a need to increase the useful life of systems and parts, or in some cases for refurbishing. In this work $410 \mathrm{NiMo}$ martensitic stainless steel, in the form of wire and rod, were deposited by electric arc and flame thermal spraying processes respectively over a CA6NM martensitic stainless steel substrate. In order to improve the layer performance the sprayed coatings were remelted by the TIG welding process. The specimens were evaluated by accelerated cavitation according to ASTM G32-1 0 standard, Vickers microhardness, optical microscopy, X-ray diffraction, SEM and EDS. The tests showed coatings with low porosity and resistant to erosion by cavitation comparable with welded coatings. Making thermal spray with reflow by the TIG process an alternative in the application of this type of coating.

\section{Introduction}

With technological advances in the area of thermal spray coatings a wide variety of materials are being developed for the most diverse application areas, increasing the performance of machines and equipments, and also with the possibility of repairing damaged areas. An important advantage is the quickness and easy application of these technologies. The different coating techniques are progressing constantly improving and optimising important properties such as adhesion, porosity and oxide content [1].

The class of soft martensitic stainless steels consists of alloys containing no more than $0.08 \% \mathrm{C}$, with 12 to $17 \% \mathrm{Cr}, 3.5$ to $6 \% \mathrm{Ni}$ and up to $2.5 \% \mathrm{Mo}$ [2], where the low carbon content promotes increased weldability, while reducing the hardness and consequently increasing the toughness in the weld metal and the ZTA. Low carbon also decreases the possibility of cold and hot cracks and solidification defects [2 and 3]. CA6NM is a soft cast martensitic stainless steel that has high yield strength and toughness, good resistance to corrosion and cavitation, and better weldability than conventional martensitic stainless steels. [4].

The objective of this work is to obtain coatings that provide increased resistance against erosion by cavitation, using the processes of thermal spraying by flame and electric arc followed by remelting with the TIG welding process.

In this study, the martensitic stainless steel $410 \mathrm{NiMo}$ in wire and rod format was used as the coating material over a cast CA6NM martensitic stainless steel substrate. In order to improve the sprayed layer, 
the coatings were remelted by the TIG welding process. The influence of the coatings chemical composition on the microstructure, porosity, microhardness and resistance to cavitation, before and after remelting were compared.

\section{Materials And Methods}

\subsection{Experimental Procedures}

Experimental procedure flowchart

Sample preparation for

- Roughness measurement;

- Porosity measurement;

- Microhardness measurement;

- Determination of phases in the coatings by DRX;

- Microstructure evaluation using optical and scanning electron microscopy;

- Cavitation erosion test.

The following materials and equipment were used to carry out the experiments:

The consumable of the thermal spray (AT) flame wire was the AWS ER410NiMo wire with a diameter of $2.4 \mathrm{~mm}$ and manual feeding. The chemical composition is shown in Table 1.

Table 1

Chemical composition of the electrode.

\begin{tabular}{|cllllllll|}
\hline 410 NiMo & \multicolumn{8}{l}{ Chemical composition } \\
\cline { 2 - 9 } & $\mathrm{C}$ & $\mathrm{Si}$ & $\mathrm{Mn}$ & $\mathrm{Cr}$ & $\mathrm{Ni}$ & $\mathrm{Mo}$ & $\mathrm{S}$ & $\mathrm{P}$ \\
\hline & 0.02 & 0.38 & 0.66 & 11.9 & 4.5 & 0.40 & 0.001 & 0.02 \\
\hline
\end{tabular}

The consumable of the electric arc thermal spray was the AWS ER410NiMo solid wire with a diameter of $1.6 \mathrm{~mm}$. The chemical composition is shown in Table 2.

Table 2

Chemical composition of the tubular wire.

\begin{tabular}{|c|llllllll|}
\hline 410 NiMo & \multicolumn{6}{l|}{ Chemical composition } \\
\cline { 2 - 9 } & $\mathrm{C}$ & $\mathrm{Si}$ & $\mathrm{Mn}$ & $\mathrm{Cr}$ & $\mathrm{Ni}$ & $\mathrm{Mo}$ & $\mathrm{S}$ & $\mathrm{P}$ \\
\cline { 2 - 9 } & 0.02 & 0.3 & 0.54 & 12.33 & 4.14 & 0.5 & 0.007 & 0.016 \\
\hline
\end{tabular}

ASTM A743 CA6NM martensitic stainless steel was used as the base metal. Its chemical composition is shown in Table 3. 
Table 3

Chemical composition of the base metal.

\begin{tabular}{rlllllllll} 
CA6NM & \multicolumn{8}{l}{ Chemical composition } \\
\cline { 2 - 10 } & $\mathrm{C}$ & $\mathrm{Si}$ & $\mathrm{Mn}$ & $\mathrm{Cr}$ & $\mathrm{Ni}$ & $\mathrm{Mo}$ & $\mathrm{S}$ & $\mathrm{P}$ \\
\hline & 0.03 & 0.30 & 0.45 & 13.0 & 3.7 & 0.34 & 0.003 & 0.02 \\
\hline
\end{tabular}

The specimens were cut to dimensions $80 \times 55 \times 12.5 \mathrm{~mm}$. For the preparation of their surface, the substrates underwent the recommended process to obtain the surface roughness necessary for the adhesion of the coating and cleaning through the abrasive equipment that ensured the cleaning grade Sa3, Standard NACE RMN - 01/70. The blasting was done in the cabin of the CMV model 659075 and the parameters used are shown in Table 4.

Table 4

Parameters used in the abrasive blasting of the samples

\begin{tabular}{|ll|}
\hline Parameters & Values used \\
\hline Abrasive & White aluminum oxide \# 30 mesh \\
\hline Type of jet employed & Pressure jet \\
\hline Abrasive transport gas & Compressed air \\
\hline Blasting pressure & 80 à 100 psi \\
\hline Blasting distance & $100 \mathrm{~mm}$ \\
\hline Angle & $90^{\circ}$ \\
\hline
\end{tabular}

To obtain the coatings, the Sulzer Metco Value Arc 300E® equipment was used with a Sulzer Metco Electric Arc Gun LCAG ${ }^{\circledR}$ pistol, with carrier gas being the compressed air, and the thermal flame sprinkler equipment with the Sulzer Metco pistol model 14E, the combustion gases were oxygen and acetylene, the carrier gas was compressed air. The parameters for each equipment are shown in Tables 5 and 6

Table 5

Deposition parameters in the electric arc process.

\begin{tabular}{|ll|}
\hline Parameter & Values used \\
\hline Chain & $130 \mathrm{~A}$ \\
\hline Voltage & $35 \mathrm{~V}$ \\
\hline Carrier gas pressure & $55 \mathrm{psi}$ \\
\hline Spray gun distance & $150 \mathrm{~mm}$ \\
\hline Wire feed rate & $1.30 \mathrm{~m} / \mathrm{min}$ \\
\hline
\end{tabular}


Table 6

Deposition parameters in the wire flame process

\begin{tabular}{|ll|}
\hline Parameter & Values used \\
\hline Material & AWS ER410NiMo with 2.4 mm diameter \\
\hline Wire feed rate & $0.45 \mathrm{~m} / \mathrm{min}$ \\
\hline Spray gun distance & $100 \mathrm{~mm}$ \\
\hline Acetylene Pressure & $14.5 \mathrm{psi}$ \\
\hline Oxygen Pressure & $30 \mathrm{psi}$ \\
\hline Compressed Air Pressure & $60 \mathrm{psi}$ \\
\hline Acetylene Flow & 60 FRM \\
\hline Oxygen Flow & 50 FRM \\
\hline Compressed Air Flow & 55 FRM \\
\hline FRM = Reference scale used by the flowmeter manufacturer. \\
\hline
\end{tabular}

For the remelting of the coatings of both processes of thermal spraying, the IMC welding equipment DIGI Plus A7 was used with a TIG torch without refrigeration and trigger. The gas used was argon with $98 \%$ purity. The basic parameters follow as follows [5].

Table 7

Reflow parameters by the TIG process.

\begin{tabular}{|ll|}
\hline Parameters & Values used \\
\hline Pulsed current & $\mathrm{I}_{\mathrm{p}}=180 \mathrm{~A} \mathrm{I}_{\mathrm{b}}=140 \mathrm{~A} \mathrm{I}_{\mathrm{m}}=160 \mathrm{~A}$ \\
\hline Time & $\mathrm{T}_{\mathrm{p}}=0.5 \mathrm{~s} \mathrm{~T}_{\mathrm{b}}=0.5 \mathrm{~s}$ \\
\hline Torch piece distance & $10 \mathrm{~mm}$ \\
\hline Welding speed & $150 \mathrm{~mm} / \mathrm{min}$ \\
\hline Gas pressure & $150 \mathrm{kgf} / \mathrm{cm}^{2}$ \\
\hline Gas flow & $11 \mathrm{~min}$ \\
\hline
\end{tabular}

For the remelting, the TIG torch was attached to the V2 equipped welding machine from IMC-Soldagem, which is an automatic torch displacement system, which allows welding and cutting in any position, with automatic displacement in two axes. The displacement with a rectangular cine was performed according to the scheme shown in Fig. 1, with a speed of $150 \mathrm{~mm} / \mathrm{min}$.

\subsection{Tests and Characterization}


First, the specimens were sandblasted with abrasive and made roughness measurements on all specimens, guaranteeing statistical similarity to the surfaces. Thereafter, the procedures for thermal spraying with wire flame and thermal spraying with electric arc were carried out and subsequently remelted. To carry out characterization and cavitation tests, the specimens were cut to a standard size according to the ASTM G32-10 standard.

From the remelted specimens, metallographic tests were performed with automatic polishing, sandpaper with granulometry from 100 to $1200 \mu \mathrm{m}$, and then polished with a polishing cloth for use with diamond paste.

The specimens were identified according to the thermal spraying technique used and subsequent remelting:

CP_AR: AT with recast electric arc

CP_BR: AT the flame remelted wire

The analyzes and tests performed were:

- Roughness measurement;

- Porosity measurement;

- Microhardness measurement;

- Determination of phases in the coatings by DRX;

- Microstructure evaluation using optical and scanning electron microscopy;

- Cavitation erosion test.

\section{Results And Discussions}

\subsection{Substrate Roughness Measurement}

Table 8 shows the result of the average of the 10 measurements right after the blasting process.

Table 8

Sample roughness after abrasive blasting

\begin{tabular}{|lll|}
\hline Samples & Average roughness Ra $(\mu \mathrm{m})$ & Roughness standard deviation $\mathrm{Ra}(\boldsymbol{\mu m})$ \\
\hline CP_AR & 5.33 & 0.45 \\
\hline CP_BR & 5.01 & 0.46 \\
\hline
\end{tabular}

The roughness averages are comparable with the literature [6], which obtained Ra roughness between 4.99 and $8.59 \mu \mathrm{m}$, using white aluminum oxide abrasive with \# 30 mesh.

\subsection{Porosity of Coatings}


Table 9 shows the results of the percentage of pores in the specimens after remelting.

Table 9

\begin{tabular}{|ll|}
\hline \multicolumn{2}{|c|}{ Porosity measurement results } \\
\hline Sample & Porosity Medium \\
\hline CP_AR & $2.3 \%$ \\
\hline CP_BR & $4.5 \%$ \\
\hline
\end{tabular}

The porosity values of the remelted coatings were low, as shown in Fig. 2 . There is a greater amount of pores in the CP_BR specimen. According to [7], argon, used in the TIG welding remelting process, can cause an increase in porosity during the process.

\subsection{Results of Measurement of Microhardness of Coatings}

In the remelted coatings, the microhardness measurements were made in 3 rows in the vertical section. Figure 3 shows the averages of the microhardness values obtained for the remelted samples.

To verify the difference in microhardness, a basic descriptive statistical analysis and an analysis of variance were generated. The measurements were divided into a remelted area, area affected by color and base metal.

Figures 4 and 5 show measurements of microhardness of the remelted area for CP_AR and CP_BR.

Through the statistical analysis presented in Fig. 4, it can be verified that there is no presence of any unusual value in each of the specimens.

In order to test the similarity of the microhardness of the recast area of the CP_AR and CP_BR specimens, an ANOVA is necessary. Table 10 shows the analysis of variance made for the microhardness measurement of the CP_AR and CP_BR samples, in the remelted area.

Table 10

Anova of CP_AR and CP_BR microhardness for remelted area.

\begin{tabular}{|llllll|}
\hline Variation & GL & SQ & QM & F calc. & P \\
\hline Treatments & 1 & 23954 & 23953.6 & 72.70 & 0.0 \\
\hline Waste & 78 & 25698 & 329.5 & & \\
\hline Total & 79 & 49652 & & & \\
\hline & GL = Degrees of freedom, SQ = Sum of squares, QM = Average squares, \\
\hline
\end{tabular}

FONTE: 0 autor (2016). 
Statistically, with a 99\% confidence level, the remelting zone of the CP_AR and CP_BR samples have different hardness averages, where CP_AR has greater hardness, this proof can be seen in Fig. 3.

Figure 5 shows measurements microhardness the area affected by the heat and CP_AR CP_BR.

Through the statistical analysis presented in Fig. 5, it can be verified that there is no presence of any unusual value in each of the specimens.

In order to test the similarity of the microhardnesses of the zone affected by the heat of the CP_AR and CP_BR specimens, an ANOVA is necessary. Table 11 shows the analysis of variance made for the microhardness measurement of samples CP_AR and CP_BR, in the area affected by heat.

Table 11

Anova of the CP_AR and CP_BR microhardness for the heat affected zone.

\begin{tabular}{|lcclcc|}
\hline Variation & GL & SQ & QM & F calc. & P \\
\hline Treatments & 1 & 7088 & 7088.4 & 19.18 & 0.0 \\
\hline Waste & 232 & 85734 & 369.5 & & \\
Total & 233 & 92823 & & & \\
\hline
\end{tabular}

Source: O autor (2016).

Statistically, with a 99\% confidence level, the heat-affected zone of the CP_AR and CP_BR samples have different hardness averages, where CP_AR has greater hardness, which can be seen in Fig. 3 .

Figure 6 shows the measured microhardness $d$ the base metal and for CP_AR CP_BR.

Through the statistical analysis presented in Fig. 6 , it can be seen that there is no presence of any outlier in each of the specimens. Table 12 shows the analysis of variance made for the microhardness measurement of samples CP_AR and CP_BR, $n$ the base metal.

Table 12

Anova of CP_AR and CP_BR microhardness for remelted area.

\begin{tabular}{|llllll|}
\hline Variation & GL & SQ & QM & F calc. & P \\
\hline Treatments & 1 & 760.9 & 760.9 & 2.7 & 0.102 \\
Waste & 183 & 51563.7 & 281.8 & & \\
\hline Total & 184 & 52324.6 & & & \\
\hline GL = Degrees of freedom, SQ = Sum of squares, QM = Average squares \\
\hline
\end{tabular}

Source: O autor (2016). 
Statistically, with a $90 \%$ confidence level, the base metal of the CP_AR and CP_BR samples have equal averages, this proof can be seen in Fig. 3.

The microhardness is less than the literature $[2,5,8]$, both in area when remelted in the heat affected zone.

\subsection{X -Ray Diffractometry (XRD) Analysis}

Figure 7 shows the diffractograms of CA6NM martensitic stainless steel and remelted samples.

In CA6NM diffractometry, the indication only of the a phase, which, comparing with the software charts and the literature, indicates a martensitic matrix typical of this steel, the austenitic phase that may be presente in the material, was also not indicated in the Works [9 and 4].

It is noted that in the refounded samples, diffractograms maintain the same peaks, in addition to the presence of $\gamma$, austenitic phase, and $\mathrm{CrN}$, phases also found by [6]. According to the author, obtaining a composite layer consisting essentially of the phases $\mathrm{CrN}$ and a gives a strong indication that these nitrides are present in the form of precipitates in the matrix resulting in a layer of high hardness and resistance. It is observed the peak of MnS, this sulfide may have arisen during the remelting process which, according to [10], in his work identified the manganese sulfide as a residual of the casting process of the alloy CA6NM. The $\mathbb{\square} \rightarrow \mathrm{Fe}_{3} \mathbf{N}$ phase, present in the remelted samples, according to [11], is an iron nitride that reduces the incubation period in the accelerated cavitation test.

\subsection{Analysis of Microstructures of Coatings Through Optical Microscopy, Scanning Electron Microscopy (SEM) and EDS}

In Fig. 8 and Fig. 9, it is possible to observe the CP_AR and CP_BR specimens, respectively, obtained after remelting with the TIG welding process, the arrows indicate the tempered martensite phase. The divisions of re-melted area, thermally affected zone and base metal were divided based on the results of microhardness.

Looking at Fig. 8 and Fig. 9, it can be seen that there was total dilution of the coating on the base metal and there is no way of knowing how far the coating has diluted in it. The temperature of the TIG welding process promoted a tempering treatment in the specimens, refining the microstructure, the area affected by the heat in relation to the base metal. There is a martensitic and austenitic microstructure, confirmed by analyzes via XRD (Fig. 7).

There is also tempered martensite, as shown in the image and is in accordance with the literature by [12]. According to the author the tempering of martensite increases considerably the tenacity and ductility and in some cases, without substantial reduction of mechanical strength. The high hardness and resistance of the tempered martensite is directly linked to the high area ratio between the cementite and matrix contours. 
According to [13], within the limits of chromium and carbon, martensitic stainless steels are totally transformed into austenite at temperatures close to $1000^{\circ} \mathrm{C}$. Cooling from these results in a totally martensitic structure. When heated in the range of 815 to $950^{\circ} \mathrm{C}$ there is partial austenitization, causing a mixed microstructure of ferrite and martensite to cool down. However, there is no evidence of $\delta$ ferrite, a phase which, according to the literature, is undesirable in martensitic stainless steels, as it tends to decrease their toughness.

Figure 10 shows the SEM image of the CP_AR coating and Table 13 indicates the quantification of elements present in the sample.

Table 13

Quantification of elements present in the CP_AR sample in Fig. 10

\begin{tabular}{|llll|}
\hline Element & $\mathbf{C r}$ & $\mathrm{Fe}$ & $\mathrm{Ni}$ \\
\hline \% Atomic & 13.27 & 79,72 & 2.82 \\
\hline
\end{tabular}

Figure 11 shows the SEM image of the CP_ BR coating and Table 14 indicates the quantification of elements present in the sample.

Table 14

Quantification of elements present in the CP_BR sample in Fig. 11

\begin{tabular}{|lllll|}
\hline Element & $\mathrm{Si}$ & $\mathrm{Cr}$ & $\mathrm{Fe}$ & $\mathrm{Ni}$ \\
\hline \% Atomic & 0.66 & 13.41 & 78.74 & 2.98 \\
\hline
\end{tabular}

In both samples the amount of elements present is similar, however in the CP_BR sample it indicated a small amount of silicon, which did not appear in the CP_AR sample.

\subsection{Cavitation Test Analysis and Result}

Figure 12 and Figure 13 show the MEV images of the CP_AR and CP_BR coatings after accelerated cavitation test.

Analyzing the surface, it can be seen that in Fig. 12 there is a greater amount of cavitated areas. It is noted that the loss of mass occurred from the depletion of eroded regions. The cavitation erosion of the CP_AR coating is greater than that of the CP_BR coating.

Figure 14 and Fig. 15 show the analysis via MEV and Tables 15 and 16 the EDS of the CP_AR and CP_BR specimens after cavitation erosion test. 
Table 14

Quantification of elements present in the CP_AR sample in

Fig. 14.

\begin{tabular}{|llllll|}
\hline Element & $\mathbf{0}$ & $\mathbf{C r}$ & $\mathrm{Fe}$ & $\mathbf{N i}$ & $\mathrm{Mn}$ \\
\hline CP_AR \% Atomic & 1.84 & 11.71 & 72.5 & 3,05 & 0,76 \\
\hline
\end{tabular}

Table 16

Quantification of elements present in the CP_AR sample in Fig. 15

\begin{tabular}{|llllllll|}
\hline Element & $\mathbf{0}$ & $\mathrm{Si}$ & $\mathrm{Cr}$ & $\mathrm{Fe}$ & $\mathrm{Ni}$ & $\mathrm{Al}$ & $\mathrm{Mn}$ \\
\hline CP_BR \% Atomic & 3.90 & 0.32 & 10.16 & 62.43 & 2.49 & 0.32 & 0.50 \\
\hline
\end{tabular}

It is observed that in the CP_AR sample there are the elements aluminum and silicon, which are not present in the CP_BR sample. Regarding the quantification of elements present before the cavitation test (Table 14 and Table 15) and after the test, it is noted that in the CP_AR specimen, the elements oxygen, aluminum, silicon and manganese appeared, and the elements chromium and iron decreased. In the CP_BR alloy, the appearance of the elements oxygen and manganese occurred, which before the cavitation test had not started, there was a decrease in the elements chromium and iron, and there was no evidence of the silicon element, which was present before the cavitation test. Nickel has not changed significantly.

Figure 16 shows the results of the mass / time losses of the accelerated cavitation test for the remelted samples.

Table 17 shows the erosion rates ( $\mathrm{mg} / \mathrm{h}$ ) for the CP_AR and CP_BR samples.

Table 17

Erosion rates in the cavitation test for CP_AR and CP_BR specimens.

\begin{tabular}{|ll|}
\hline Specimens & Erosion Rate $(\mathrm{mg} / \mathrm{h})$ \\
\hline CP_AR & 4.25 until $8 \mathrm{~h}$ e 0.65 after $8 \mathrm{~h}$ \\
\hline CP_BR & 0.21 \\
\hline
\end{tabular}

The erosion rate for the $\mathrm{CP}_{-}$AR sample was $4.25 \mathrm{mg} / \mathrm{h}$ up to 8 hours of testing, after this test time the rate dropped to $0.65 \mathrm{mg} / \mathrm{h}$, this was because, unlike the other samples, there was the incubation time where the erosion rate has reached its maximum value. The erosion rate of the CP_BR sample was $0.21 \mathrm{mg} / \mathrm{h}$, which is a value much lower than that found in the literature by $[14,5,6,11]$. Both samples have better results than the literature and [5].

This result is related to the microhardness of the remelted area, where CP_BR obtained values lower than CP_AR, as well as the percentage of elements present in each sample. There is no evidence of carbon in the samples improving hardness which may be linked to the low erosion rate of the specimens, the 
CP_BR sample has a higher percentage of manganese, compared to the CP_AR sample, which improves the toughness of the material.

\section{Conclusions}

According to the results obtained and comparing them with the literature, through Vickers microhardness and cavitation erosion tests, and analyzes of MO, SEM, EDS, XRD and pore percentage, it can be concluded that:

The remelted specimens had a very satisfactory microstructure, the coatings diluted completely in the base metal without forming ZTA. The heat generated in the remelting process led to a refinement in the material's microstructure for both coatings. In the analysis I saw the XRD there is no difference in phases present in both recast coatings.

The specimen covered by the thermal arc sprinkling process and remelted with the TIG welding process had a lower percentage of pores and greater microhardness in the remelted area and in the area affected by heat, however the microhardness is less than that found in the literature. In the accelerated cavitation test, the specimen had a satisfactory result in relation to the literature.

The specimen coated by the process of thermal spersion to flame wire and remelted with TIG had less microhardness than the coating sprayed by another process and in the literature. In the accelerated cavitation test it was the sample with the best result, being much better than the results found in the literature.

All coatings have satisfactory results for the proposed study, and can be applied as coatings against erosion by cavitation or even for the surface recovery of components already cavitated.

\section{Declarations}

\section{Acknowledgements}

The authors would like to thank the laboratories LEME (UTFPR), CMCM (UTFPR), LABATS (UFPR), LEME (UFPR), LORXI (UFPR), LAMATS (UFPR), LACTEC and PGMEC.

-Ethical Approval - Not applicable.

-Consent to Participate - Not applicable.

-Consent to Publish - All authors read and approved the final manuscript.

-Authors Contributions - EFTO produced, analyzed the specimens and wrote the manuscript; PSOF helped during the work, did the statistical analysis and helped to correct the manuscript; JFS helped during the 
work and in the correction of the manuscript; PVPM helped to correct the manuscript; JRSM helped to correct the manuscript.

-Funding - Not applicable

-Competing Interests - Not applicable

-Availability of data and materials - The data used for this manuscript are in the work of OLIVIO, E. F. T.; Análise do Revestimento de 410NIMO Depositado por Aspersão Térmica no Aço Inoxidável Martensítico CA6NM Contra a Erosão por Cavitação. Tese de Doutorado. Universidade Federal do Paraná. Curitiba, 2016.

\section{References}

[1] MENEZES, D. D.; Avaliação da Resistência à Corrosão de Revestimentos de Alumínio Aplicados pelas Técnicas de Arco Elétrico e Chama Convencional, em meio Cloreto. Rio de Janeiro. Tese de Doutorado. Universidade Federal do Rio de Janeiro. 2007.

[2] HENKE, S. L.; Desenvolvimento de Procedimento de Soldagem de Aço Inoxidável Martensítico Macio tipo CA 6NM Sem tratamento Térmico Posterior. Dissertação de Mestrado, Universidade Federal de Santa Catarina, Florianópolis, 1998.

[3] GONÇALVES, B. H. B.; Estudo comparativo da resistência à erosão por cavitação do metal de solda depositado por um arame tubular tipo $13 \% \mathrm{Cr}-4 \% \mathrm{Ni}-0,4 \% \mathrm{Mo}$ e do aço fundido ASTM A 743 CA6MN. Dissertação de Mestrado, Belo Horizonte, Universidade Federal de Minas Gerais, 2007.

[4] NOVICKI, N. ; CASAS, W. J. P. ; HENKE, S. L.; Tenacidade à Fratura do Aço CA6NM Temperado e Revenido e de sua Junta Soldada sem TTPS. Revista Soldagem \& Inspeção, v. 13, p. 25-31, 2008.

[5] PEREIRA, S.A. 2000. 136p. Desenvolvimento de Procedimento de Reparo por Soldagem em Aços Inoxidáveis Martensíticos com Metal de Adição Similar sem TTP. Dissertação (mestrado) - Universidade Federal de Santa Catarina, Florianópolis.

[6] ALLENSTEIN, A.N. Estudo da Resistência à Cavitação do Aço Inoxidável Martensítico CA6-NM Nitretado por Plasma: 2007. 113p. Dissertação (mestrado) - Universidade Federal do Paraná, Curitiba.

[7] PUKASIEWICZ, A.G.M. Desenvolvimento de revestimentos Fe-Mn-Cr-Si-Ni resistentes à cavitação depositadas por aspersão ASP. 2008. 192p. Tese (doutorado) - Universidade Federal do Paraná, Curitiba.

[8] BEHENE, L.; Estudo da alteração de parâmetros do processo de soldagem plasma com alimentação de vareta em substrato de aço ASTM 743 tipo CA6NM. Dissertação de mestrado. Universidade Federal do Paraná. Curitiba, 2014. 
[9] CUNHA, M. A. R.; Modelagem De Cavitação Bifásica em um Rotor de Bomba Centrífuga. Dissertação de mestrado. Universidade Federal do ABC, Santo André, 2013.

[10] ALMEIDA, L.F.C.B.de. 2015. 133p. Avaliação da influência de aplicação de vibração mecânica na microestrutura e em características mecânicas de juntas do aço inoxidável martensítico CA6NM soldadas pelo processo FCAW. Dissertação (mestrado) - Escola de Engenharia da Universidade de São Paulo, Lorena.

[11] ESPITIA, L. A.; VARELA, L.; PINEDO, C. E.; TSCHIPTSCHIN, A. P.; Cavitation erosion resistance of low temperature plasma nitride martensitic stainless steel. Elsevier B.V. All rights reserved. p 449-456. 29.dez.2012.

[12] STROBEL, E. Filho; LIMA, A.P.; MARIANO, N. A.; Efeito do tratamento térmico na caracterização microestrutural e das propriedades mecânicas de um aço inoxidável martensítico do tipo 13Cr5Ni0,02C. REM: R. Esc. Minas, Ouro Preto, 60(1): 123-127, jan. mar. 2007.

[13] HENKE, S. L.; Efeito da soldagem plasma pulsada na microestrutura e resistência à fadiga de um aço inoxidável supermartensítico. Tese de Doutorado. Universidade Federal do Paraná, Curitiba, 2010.

[14] BOCCANERA, L.F. 1999. 149p. Resistência a Erosão por Cavitação de Revestimentos Depositados por Soldagem e Aspersão Térmica. Tese (doutorado) - Universidade Federal de Santa Catarina, Florianópolis.

\section{Figures}

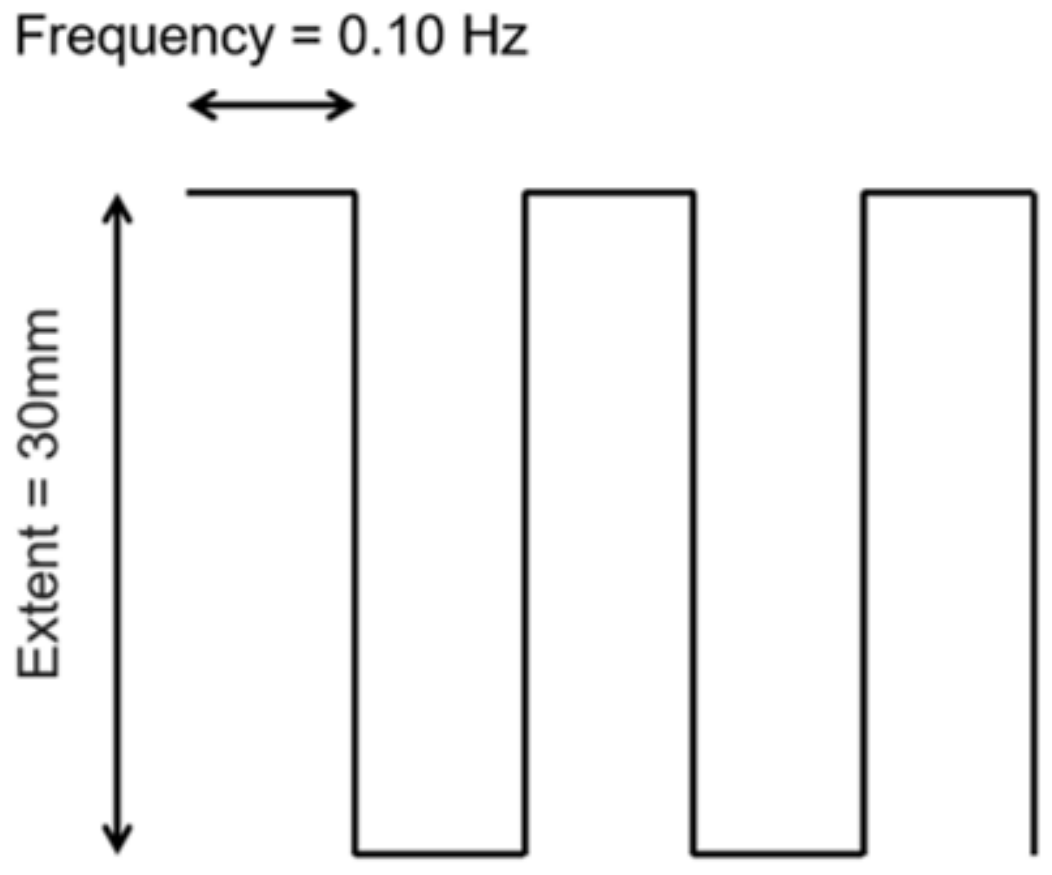

Figure 1 
Rectangular reflow path with TIG torch.



Figure 2

Porosity of the remelted coatings. A) recoated electrical arc AT coating. B) coating obtained by AT the remelted wire flame. 


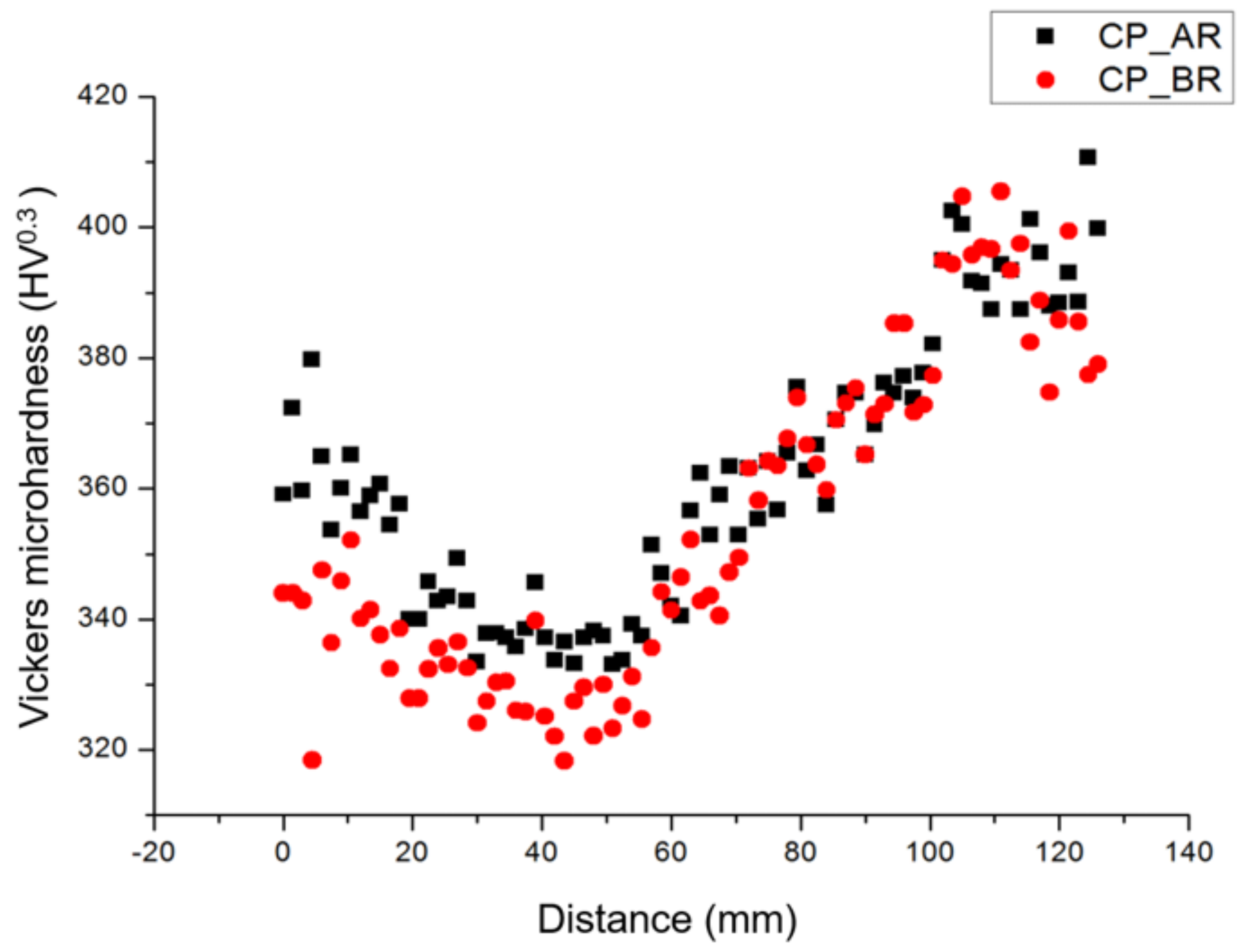

Figure 3

Average microhardness of the remelted coatings. 
Sample CP_AR e CP_BR

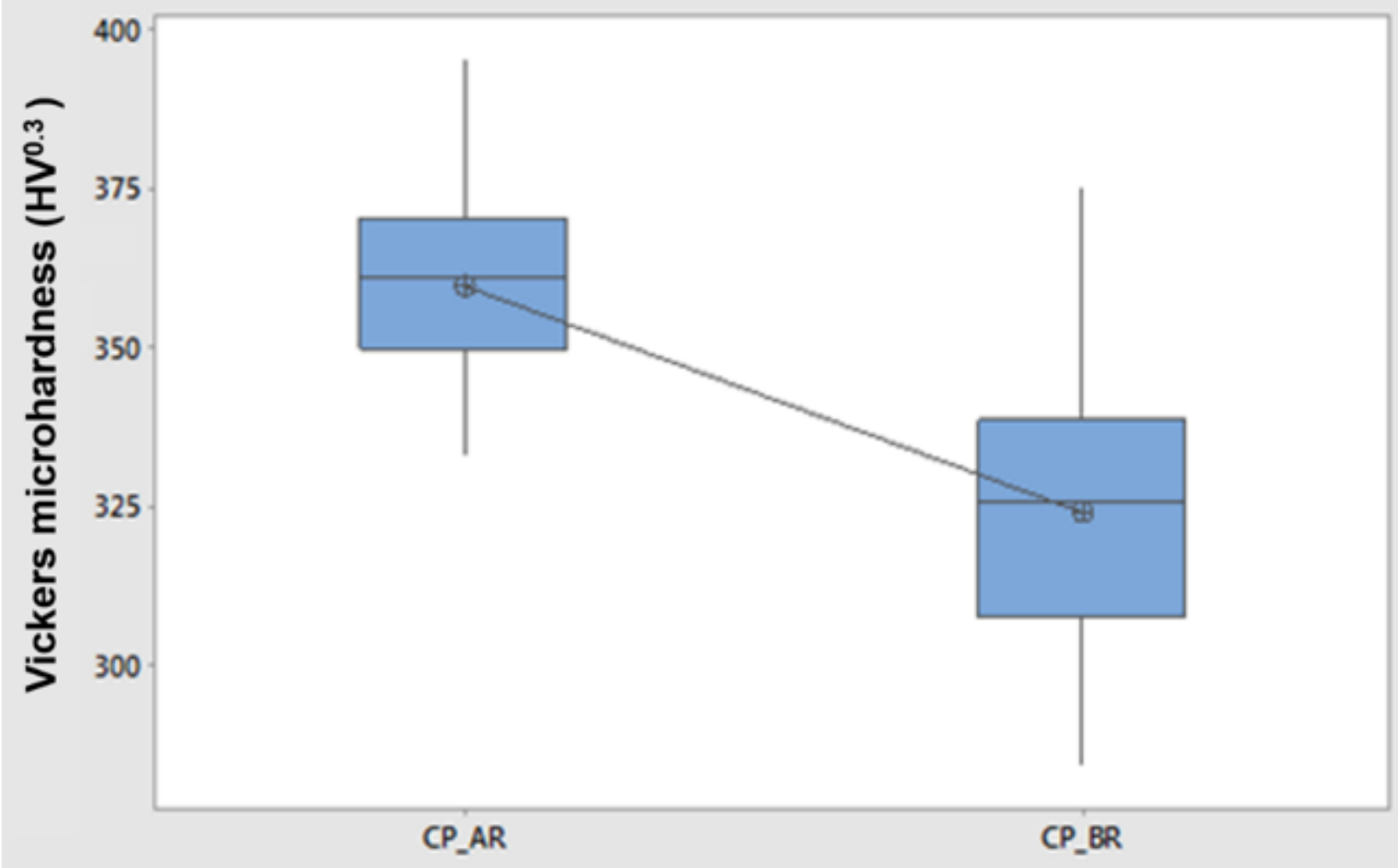

Figure 4

Statistical analysis of microhardness in the remelted area. 


\section{Sample CP_AR e CP_BR}

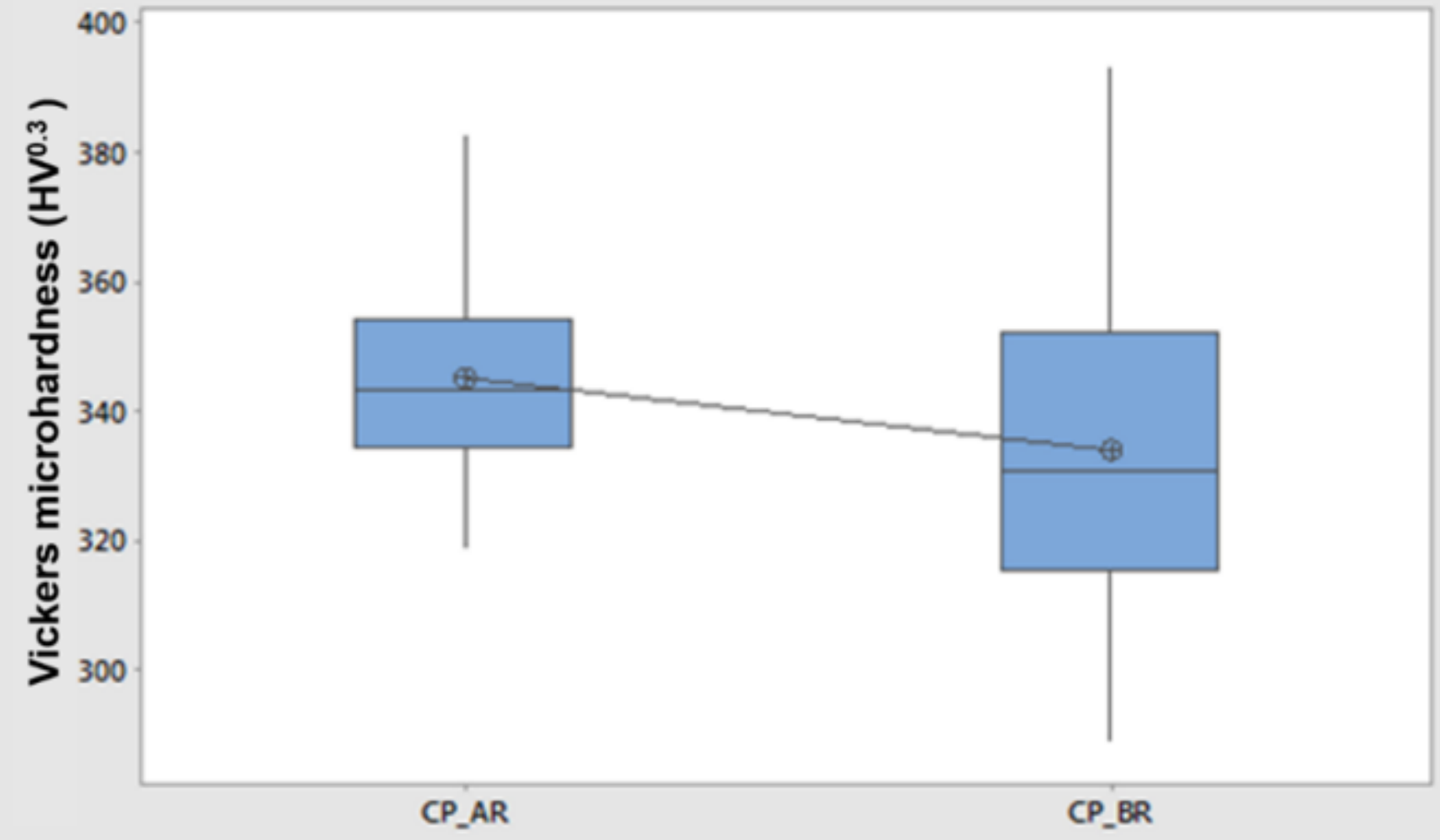

Figure 5

Statistical analysis of microhardness in the area affected by heat. 
Sample CP_AR e CP_BR

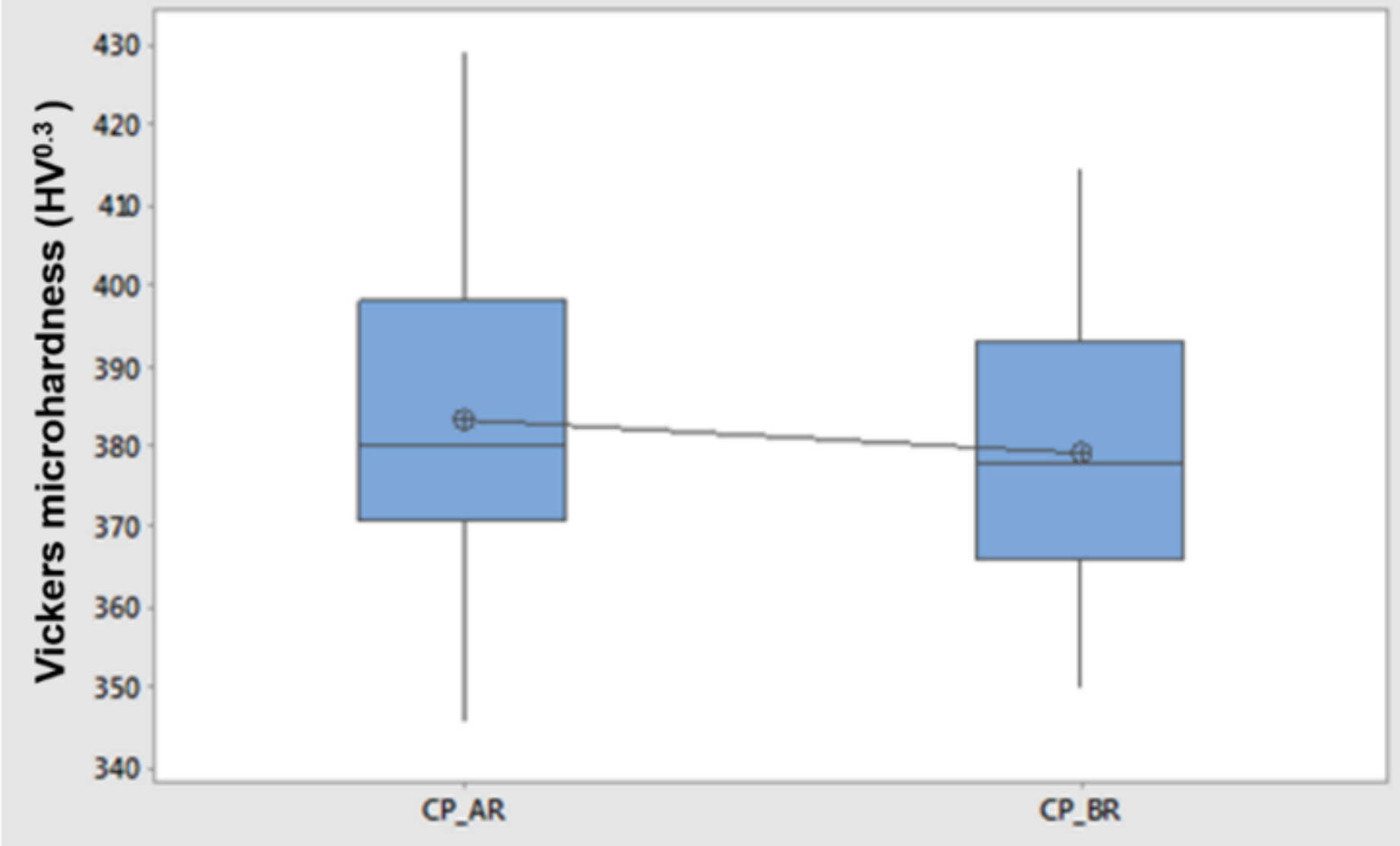

Figure 6

Statistical analysis of microhardness in the base metal. 

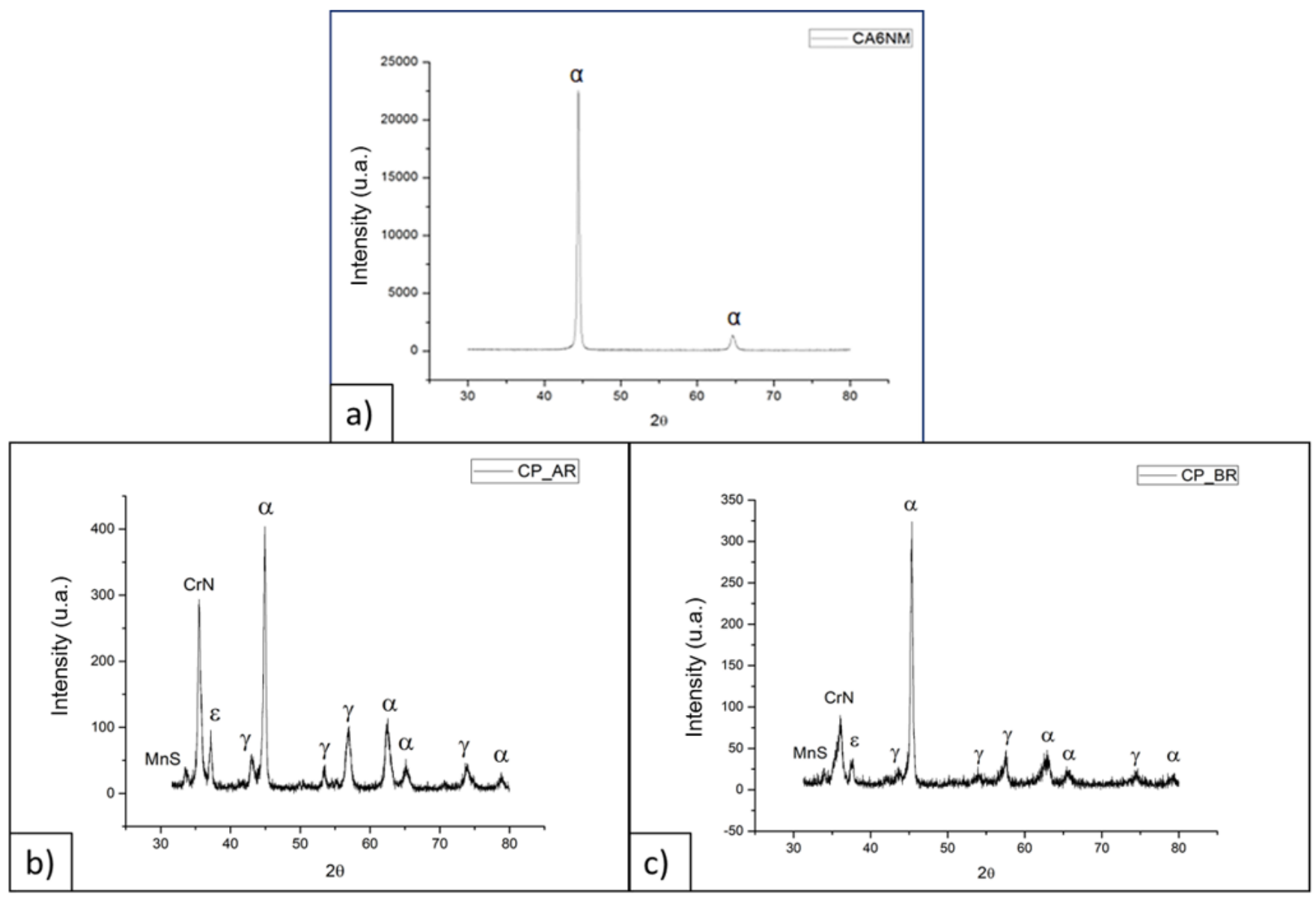

Figure 7

a) DRX CA6NM. b) DRX sample CP_AR. c) DRX sample CP_BR. 




Figure 8

CP_AR specimen - covered by an electric arc. 


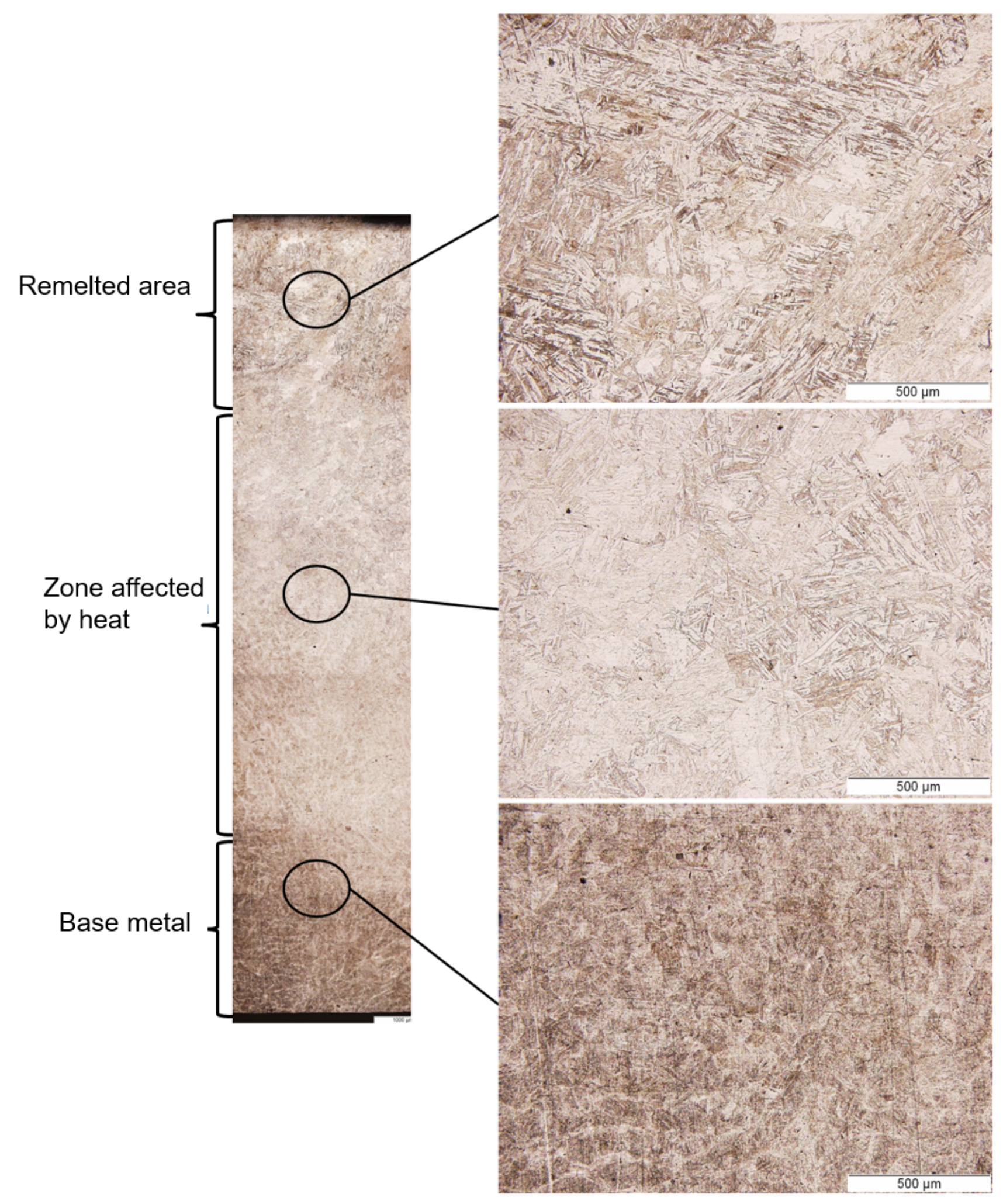

Figure 9

CP_BR specimen - coated with wire flame. 

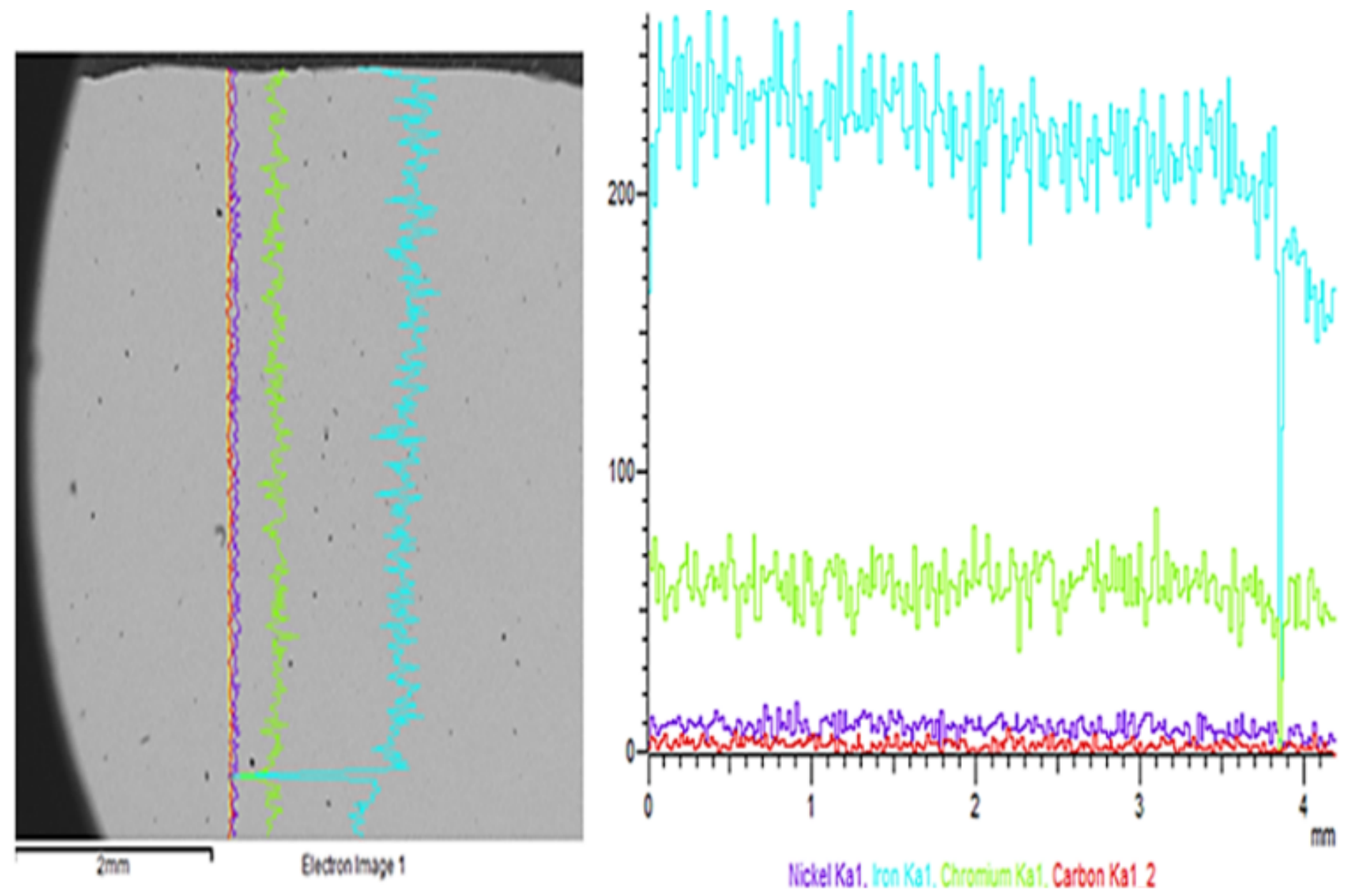

Figure 10

Image of MEV the CP_AR sample. 

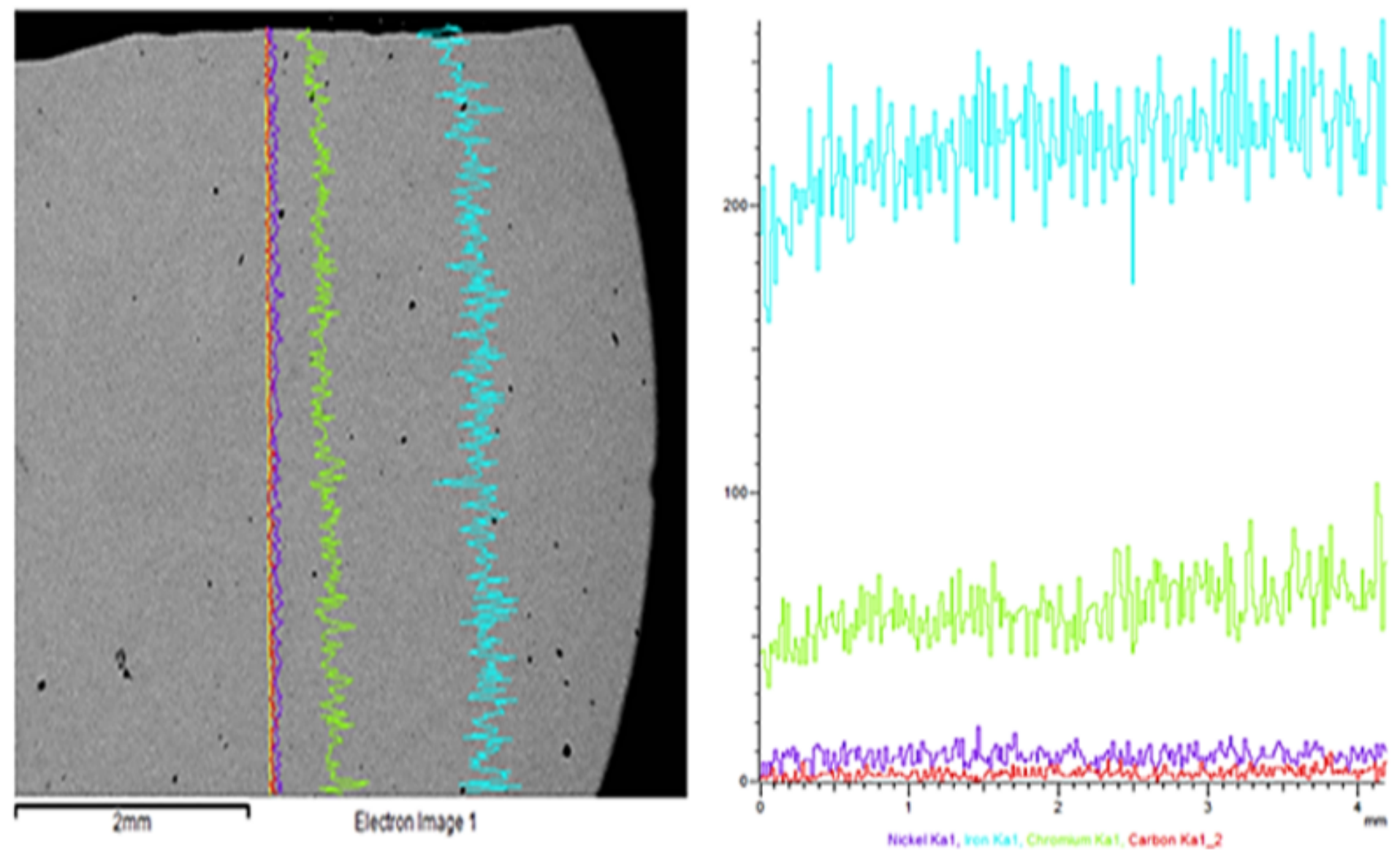

Figure 11

Image of MEV the CP_BR sample. 


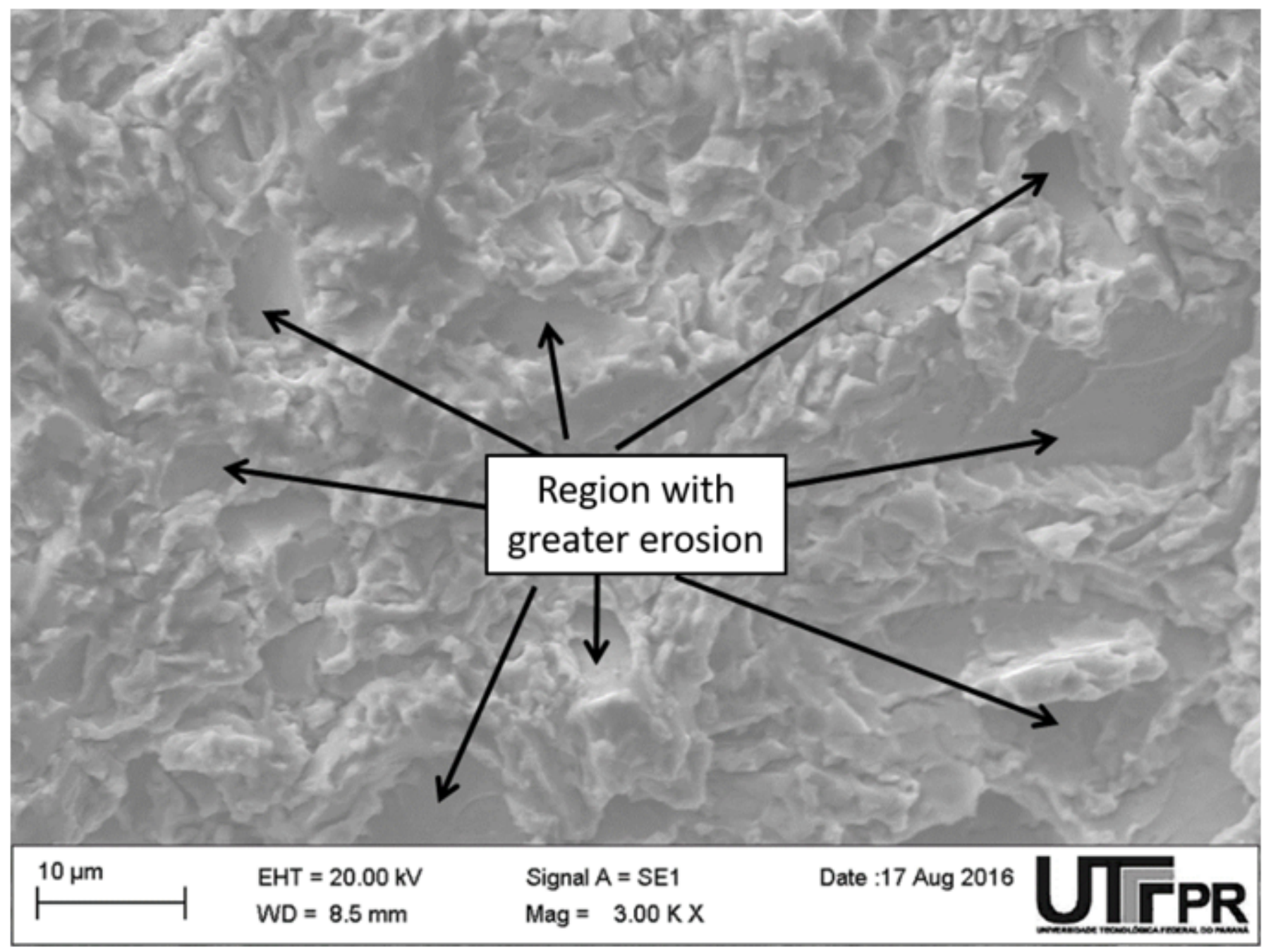

Figure 12

MEV image of CP_AR coating after accelerated cavitation test. 


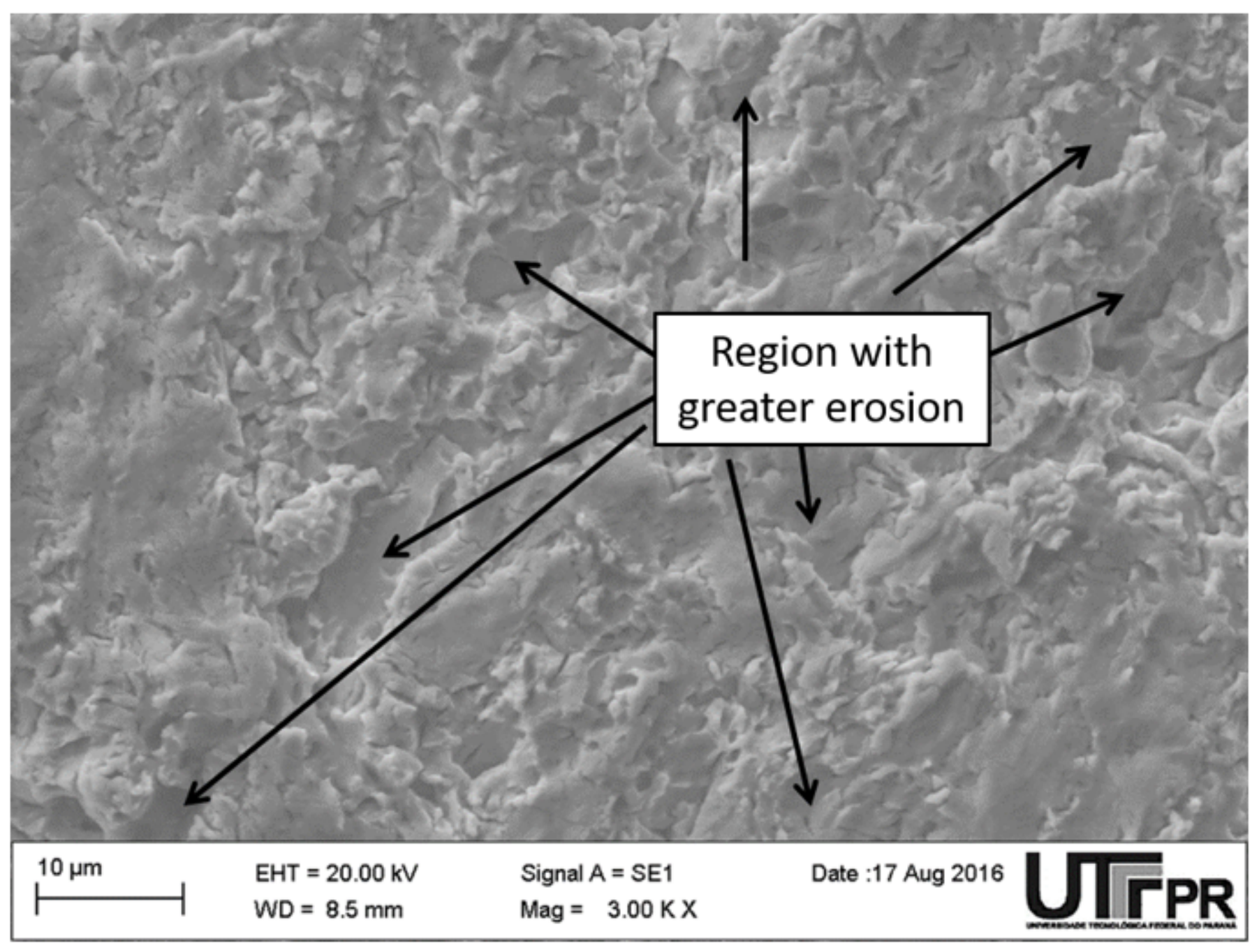

Figure 13

MEV image of the CP_BR coating, after accelerated cavitation test. 


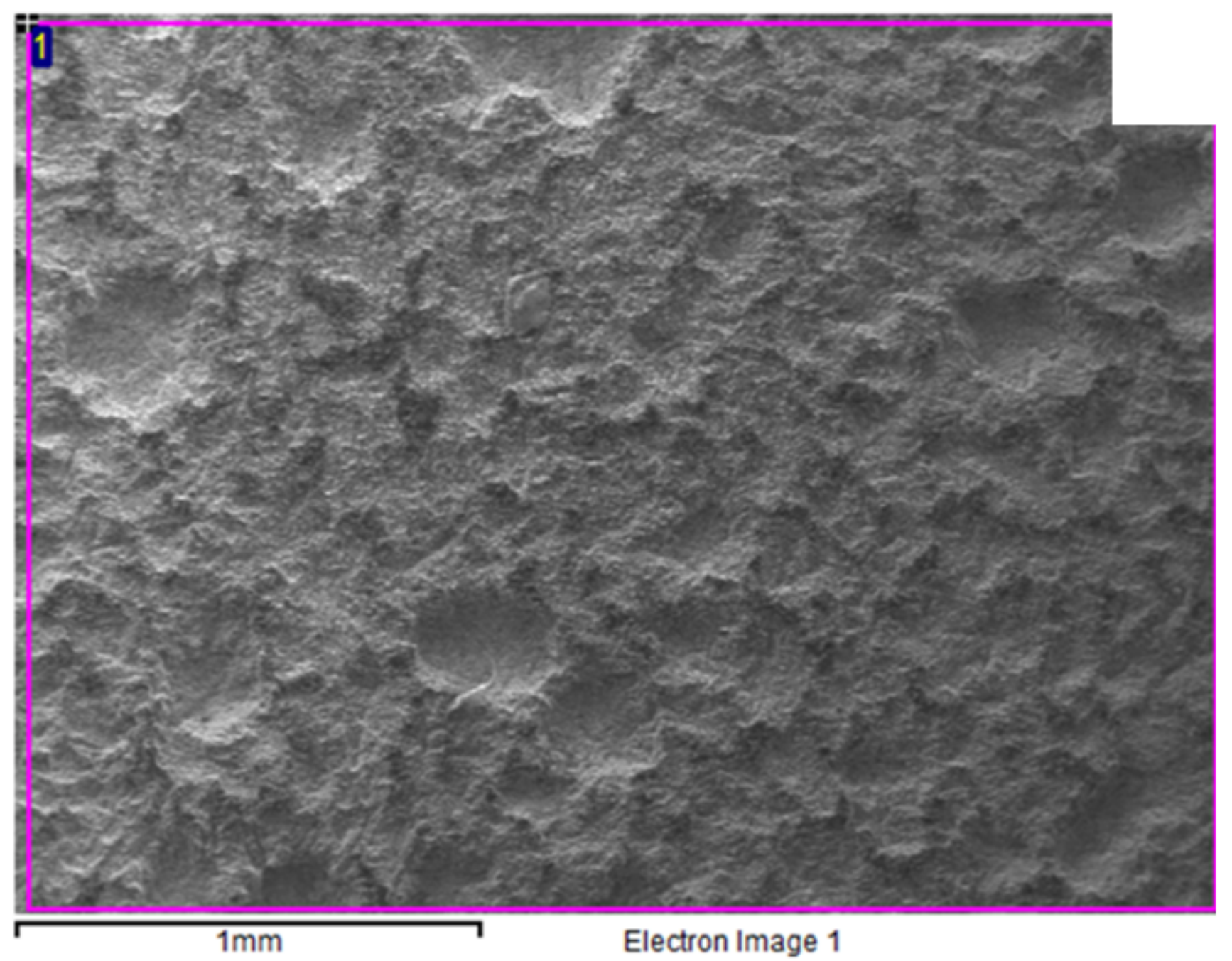

Figure 14

CP_AR specimen after cavitation test. 


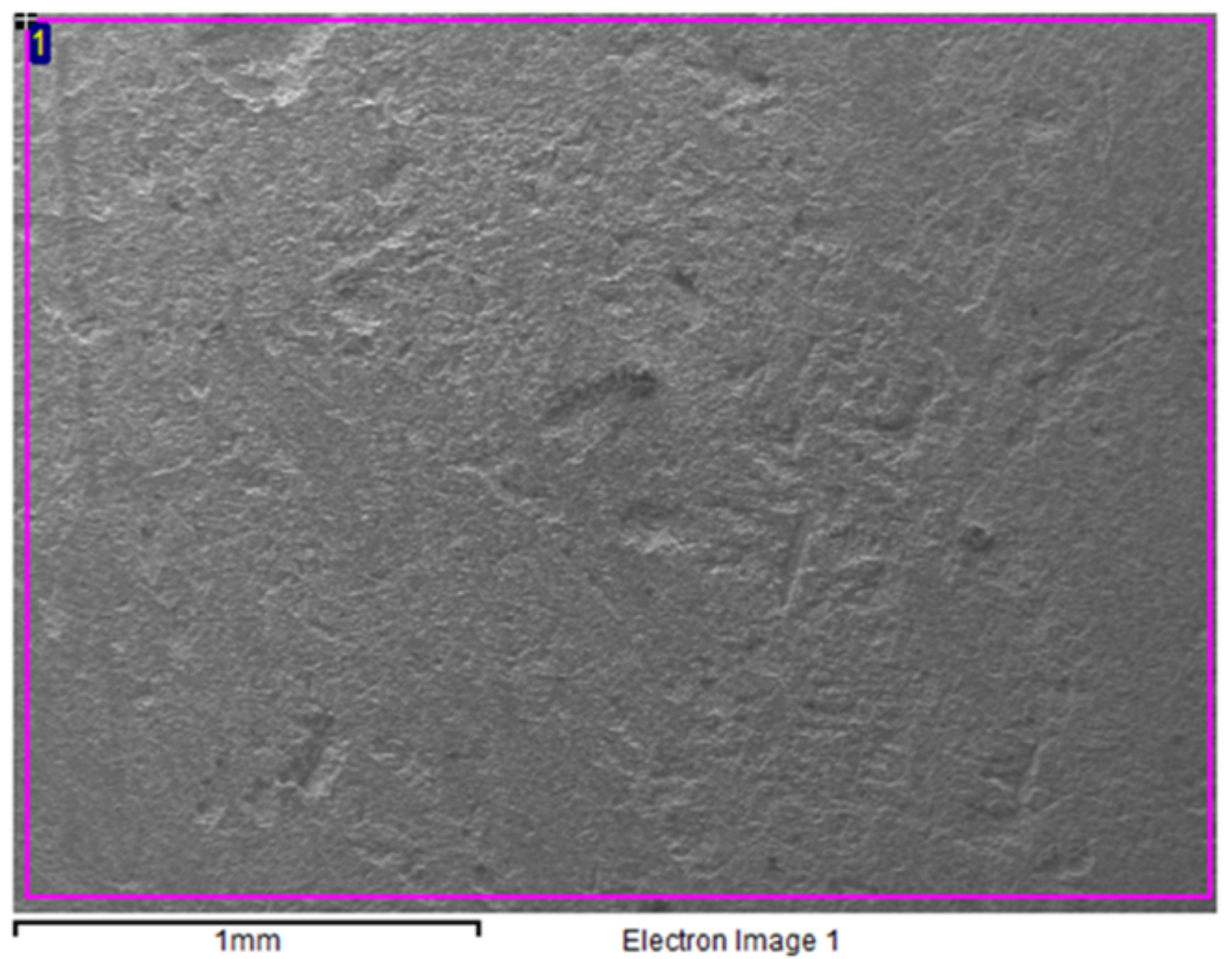

Figure 15

Specimen CP_BR 


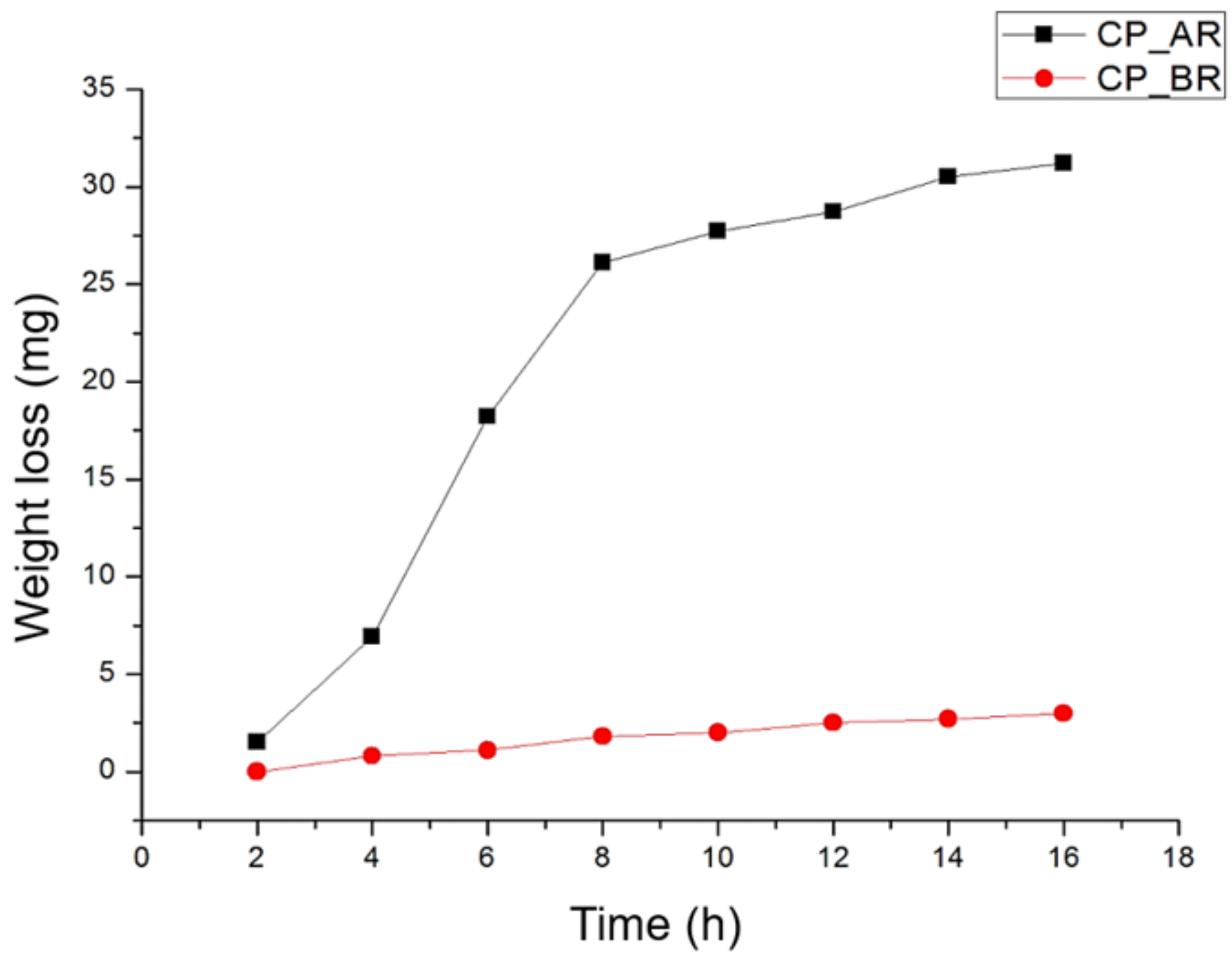

Figure 16

Result of the cavitation erosive test for samples CP_AR and CP_BR. 